\title{
Identification and Analysis of Diversity of Soil Microorganism Colonies in Limestone Reclamation Land
}

\author{
Supiana Dian Nurtjahyani ${ }^{*}$, Dwi Oktafitria ${ }^{2}$, Sriwulan $^{1}$, Ahmad Zaenal Arifinn $^{3}$, Eko Purnomo $^{4}$ \\ ${ }^{1}$ Biology Education Study Program, Faculty of Teacher and Educational Science, PGRI Ronggolawe University \\ ${ }^{2}$ Department of Biology, Faculty of Mathematic and Natural Science, PGRI Ronggolawe University \\ ${ }^{3}$ Departement of Mathematic, Faculty of Mathematic and Natural Science, PGRI Ronggolawe University \\ J1. Manunggal No. 61 Tuban-62381, East Java, Indonesia \\ ${ }^{4}$ PT. Semen Indonesia Tbk Gresik, Semen Indonesia Group \\ Jl. Veteran No.93, Gapurosukolilo, Gresik-61122, East Java, Indonesia \\ *Corresponding author: diananin39@gmail.com
}

\begin{abstract}
Reclamation of land used for mining is very important because it is related to microbial activity in the soil which has an impact on soil fertility. The purpose of this study is to identify and analyze the diversity of bacterial colonies in the reclaimed land of the former Limestone Mining. The method used in this research was a laboratory experimental method. The results of the study showed that 6 bacterial isolates were found and the highest total plate count in GPS land (GPS system) is $1.97 \times 10^{6} \mathrm{cfu}$, the dominant colony characteristics were irregular shapes, flat edges and milky white color.
\end{abstract}

Keywords: bacterial colony; diversity; isolate; reclamation land; soil

\section{INTRODUCTION}

Reclamation of a former limestone quarry is an obligation that must be carried out by companies or holders as stipulated in the Minister of Energy and Mineral Resources decree No. 7 of 2014[1]. The success of a reclamation is largely determined by many things, including aspects of land use, fertility of the planting media, technical planting and maintenance of plants.

Reclamation has been carried out by PT Semen Indonesia (Persero) Tbk since 2010 until now. Along with the increase in years, modifications in planting are always done, not only by doing conventional systems, but also Groove Planting Systems (GPS). Since the initial reclamation in 2010, 2014 and 2016, the method used is the conventional method. This conventional method is carried out by distributing topsoil evenly. The implementation of this reclamation activity is closely related to the biodiversity in the reclamation land, including the biodiversity of soil microorganisms.

Biodiversity of soil microorganisms can be used as an indicator of land quality. This is because, the presence of soil microorganisms can provide a number of benefits for plant growth, including helping provide nutrient availability, helping to mobilize nutrients, helping to produce Plant Growt Regulator (PGR), and as a pathogen biocontrol agent[2]. In addition to bacteria there are also mycorrhizae that can help soil fertility [3]. Therefore this study aims to identify and analyze the diversity of soil microbial colonies in groups of bacteria in the reclaimed land of limestone mining.

\section{METHODS}

This research is an exploratory study, the method used is a laboratory experimental method carried out in the biology laboratory of the University of PGRI Ronggolawe, Tuban. Research samples from the former reclaimed land of limestone mining PT Semen Indonesia Tbk.

\section{Data Collection and Analysis of Soil Microorganisms}

Analysis of soil microorganism diversity in this study was limited to soil bacterial groups. This analysis process is carried out through several stages, which include isolation, purification, and characterization of bacterial isolates obtained.

Bacterial isolation was carried out by taking soil samples from the post-limestone quarry land that was reclaimed with conventional systems and grooves. Soil samples were taken at 5 points from each location. Then a serial dilution was carried out on the soil sample that has been taken. Dilutions were done at levels $10^{-4}, 10^{-5}$, and $10^{-6}$. The diluted samples were then inoculated on NA (Nutrient Agar) media and incubated at room temperature for 2 x 24 hours. The isolates obtained from the isolation process were then purified. Purification was carried out by the quadrant method [4] [5]. After obtaining a single colony, the isolates were characterized. Then identified 
based on characteristics that refer to Bergey's Manual of Determinative of Microorganism [6].

\section{RESULTS AND DISCUSSION}

Results

The results of the observation of the morphology of the bacterial colonies that were isolated from soil samples in the land of the former PT Semen Indonesia limestone are presented in Figure 1 and Table 1. In addition to colony morphology identification, up to this stage colony counts have also been made using the Total Plate Count (TPC) method. Table 2 shows the results of the calculation of bacterial colony TPC from the former limestone quarry of PT. Semen Indonesia (Persero) Tbk.

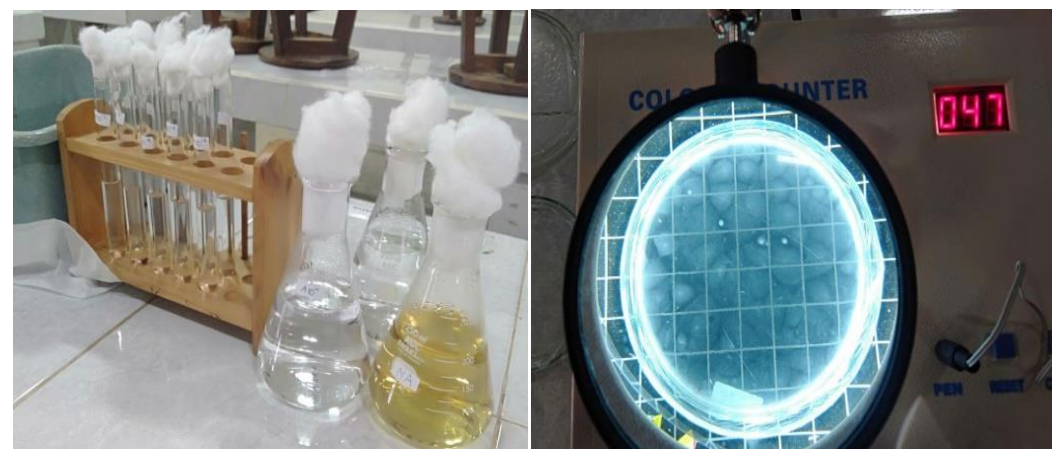

Figure 1. A: Culture Bacteria; B: Isolates and colonies of soil bacteria from the reclaimed land of the former limestone quarry

TABLE I

THE MORPHOLOGY OF THE BACTERIAL COLONIES ISOLATED FROM SOIL ON CRETACEOUS MINE

\begin{tabular}{|c|c|c|c|c|c|c|}
\hline \multirow{2}{*}{ No } & \multirow{2}{*}{ Isolate } & \multirow{2}{*}{$\begin{array}{c}\text { Origin of } \\
\text { Isolates }\end{array}$} & \multicolumn{4}{|c|}{ Morphology } \\
\hline & & & Shape & Color & Edge & Surface \\
\hline 1 & Isolate 1 & $\begin{array}{l}\text { Conventional } \\
\text { Systems }\end{array}$ & Irregular & Thin white & Flat & Convex \\
\hline 2 & Isolate 2 & $\begin{array}{l}\text { Conventional } \\
\text { Systems and } \\
\text { Groove } \\
\text { Planting } \\
\text { Systems (GPS) }\end{array}$ & Round & Milk white & Flat & Convex \\
\hline 3 & Isolate 3 & $\begin{array}{l}\text { Conventional } \\
\text { Systems and } \\
\text { Groove } \\
\text { Planting } \\
\text { Systems (GPS) }\end{array}$ & $\begin{array}{l}\text { Irregular, } \\
\text { small }\end{array}$ & White & Flat & Flat \\
\hline 4 & Isolate 4 & $\begin{array}{l}\text { Conventional } \\
\text { Systems and } \\
\text { Groove } \\
\text { Planting } \\
\text { Systems (GPS) }\end{array}$ & $\begin{array}{l}\text { Small } \\
\text { round }\end{array}$ & White & Flat & Convex \\
\hline 5 & Isolate 5 & $\begin{array}{l}\text { Conventional } \\
\text { Systems and } \\
\text { Groove } \\
\text { Planting } \\
\text { Systems (GPS) }\end{array}$ & $\begin{array}{l}\text { Irregular, } \\
\text { big }\end{array}$ & White & Flat & Flat \\
\hline 6 & Isolate 6 & $\begin{array}{l}\text { Groove } \\
\text { Planting } \\
\text { System (GPS) }\end{array}$ & Irregular & $\begin{array}{c}\text { Transparent } \\
\text { white }\end{array}$ & Flat & Convex \\
\hline
\end{tabular}


TABLE II

AVERAGE OF TOTAL PLATE COUNT OF BACTERIA FROM SOIL ON CRETACEOUS MINE

\begin{tabular}{cccccc}
\hline \multirow{2}{*}{ No } & Sample Origin & \multicolumn{3}{c}{ Rate of Dilution } & TPC value (cfu) \\
\cline { 3 - 5 } & $10^{-4}$ & $10^{-5}$ & $10^{-6}$ & \\
\hline 1 & Conventional & 116 & 263 & 525 & $4.9 \times 10^{5}$ \\
\hline 2 & $\begin{array}{l}\text { Groove Planting } \\
\text { System (GPS) }\end{array}$ & 567 & 231 & 140 & $1.97 \times 10^{5}$ \\
\hline
\end{tabular}

\section{Discussion}

In Table 1 it can be seen that from the isolation there were 6 isolates obtained. The six isolates consisted of Isolate 1 which was only found in soil samples taken from conventional systems. Isolate 2 , Isolate 3 , Isolate 4 , and Isolate 5 were found from both Groove Planting System (GPS) and conventional soil samples. Whereas Isolate 6 was only found from soil samples taken on GPS systems.

In Table 2 it can be seen that the total bacterial plate count from land with a GPS system $\left(1.97 \times 10^{6} \mathrm{cfu}\right)$ is higher than conventional land $\left(4.9 \times 10^{5} \mathrm{cfu}\right)$. These results indicate that the number of bacterial colonies found on GPS land is higher than conventional land. With more and more bacteria this Soil fertility depends on the physical, chemical, and biological soil conditions. Soil physical conditions include effective depth, texture, structure, humidity, and soil air condition. Soil chemical conditions include: soil reaction (soil $\mathrm{pH}$ ), base saturation, and organic matter, abundance of nutrients, nutrient reserves, and availability of nutrients for plants. Biological conditions of the soil include: microbial activity of organic material remodeling in the process of humification, and binding of nitrogen free from the air. Evaluation of soil fertility can be done in several ways, namely through visual observation of plant deficiency symptoms [7] [8] [9].

The number of bacterial colonies in the GPS environment is higher because of the GPS environment because the carrying capacity of the environment in the form of nutrients both macro and micro is better than conventional ones. This is in line with Erfandi's research, 2017[10] which states that bacteria have an important role in the process of decomposition of organic matter, especially at high humidity levels. Characteristics of bacterial colonies found are the convex surface dominant with milky white color. This diverse bacterial colony shows the diversity of soil microbes. The edges of the colonies that were found all had flat edges, while the dominant colony was irregularly rounded, the characteristics of the bacterial colonies found in the former limestone quarry had different diversity.

Bacterial colonies have special properties in solid media, where the shape of the colony can be described as dot, round or circular, filamentous and irregular. The surface of the colony can be flat, arise flat, curved, bulging, hilly and similar to the crater, while the edges of the colony can be intact or whole, split or lobate, swim or filamentus and curled. In color, bacterial colonies are mostly whitish or yellowish in color [11].

Naturally in polluted soils there are biosurfactantproducing bacteria. Biosurfactants are compounds produced by microorganisms that function to reduce the surface tension of the liquid so that the bioremediation process can take place properly. With the presence of biosurfactant-producing bacteria, the process of degradation of the polluted soil environment will proceed well [12] [13].

The reduced microbial activity in the soil will also affect soil density, because it can dissolve nutrients in the soil. Microorganisms in the soil can also use the results of pollutants for metabolism so that the number increases and can help soil fertility [14] [15] [16]. The results of this study indicate there are 6 isolates of which 5 isolates were obtained from the GPS environment and conventional, while the other 1 from the conventional environment. From these data, the combination of conventional environment and GPS environment provides more environmental support for bacterial growth because the remnants of the mining area still contain nutrients and pollutants that can be used for bacterial metabolism.

\section{IV.CONCLUSION}

There are 6 bacterial isolates found in conventional land and GPS land in the former limestone quarry. The total bacterial plate count from land with GPS systems $\left(1.97 \times 10^{6} \mathrm{cfu}\right)$ is higher than conventional land $(4.9 \mathrm{X}$ $10^{5} \mathrm{cfu}$ ). Bacterial colonies on limestone quarry have the characteristics of irregular shape, flat edges and the color of milky white colonies. 


\section{ACKNOWLEDGMENT}

The authors would like to thank PT Semen Indonesia (Persero) Tbk of research funding facilities, Biology Laboratory Staff of ITS Surabaya and Biology Laboratory Staff of PGRI Ronggolawe University Tuban for their cooperation in processing and analyzing samples.

\section{REFERENCES}

[1] Minister of Regulation Energy and Mineral Resources Republic Indonesia. 2014. Decrre No. 7 of 2014 about Implementations of Reclamation and Post Mine in Mineral and Coal Mining Business Activities. Access on 23 March 2019.

[2] Hari K, TA Wahyudi, E Husen. 2017. Pengaruh Rizobakteria Pemacu Tumbuh Dam Toleran Kekeringan Serta Kelimpahan Dan Aktivitas Mikroba Tanah Terhadap Tanaman Jagung (Zea mays L.). Biospecies 10(1): 25-36.

[3] Nurtjahyani SD, D Oktavitria, S Wuan, I Cintamulya, N Maulidina, E Purnomo. 2018. Identifikasi Dan Karakterisasi Keanekaragaman Mikoriza Pada Lahan Reklamasi Bekas Penambangan Batu Kapur Di Kabupaten Tuban. In Prosiding Seminar Nasional VI Hayati 2018, pp. 291-99.

[4] Lay B. 1994. Analisis Mikroba di Laboratorium, Grafindo Persada, Jakarta.

[5] Cappuccino JG, N Sherman. 2008. Microbiology: A Laboratory Manual, Pearson, New York.

[6] Sneath PHA, NS Mair, ME Sharpe, JG Holt. 1986. Bergey's Manual of Systematic Bacteriology Vol.2, Williams and Wilkins, Baltimore.
[7] Sriwahyuni. 2012.Rehabilitation of Mine wasteland PT. Inco Sorowako with Organic Matter, Bacteria Solubilizing of phosphate and Bacteria Reducing of Nickel. Jurnal Riset Industri, 6(2): 149-155.

[8] Lambui O, M Jannah. 2017. Isolation and Identification of Soil Bacteria in Forest around Lake Kalimpa'a, Lore Lindu National Park Area, Central Sulawesi. Online Journal of Natural Science, 6(1):73-82.

[9] Neneng L, Saraswati D. 2019. Reclamation of Degraded Land Ex Gold Mining Area using Bioremediation and Phytoremediation Methods. EnviroScienteae Vol. 15(2):216-225.

[10] Erfandi D. 2017. Pengelolaan Lansekap Lahan Bekas Tambang: Pemulihan Lahan dengan Pemanfaatan Sumberdaya Lokal (In-Situ. Jurnal Sumberdaya Lahan Vol. 11(2): 55-66.

[11] Dwijoseputro, D. 2005. Dasar-Dasar Mikrobiologi, Djambatan, Jakarta.

[12] Gautam KK, VK Tyagi. 2006. Microbial Surfactants: A Review. J. Oleo Sci. 55(4): 155-166.

[13] Utami DS, Priyani N, Munir E. 2012 Isolasi dan uji potensi bakteri tanah pertanian berastagi sumatera utara dalam mendegradasi fungisida antracol berbahan aktif propineb. https://media.neliti.com/media/publications/221113 -none.pdf.

[14] Soedarsono MJ, L Endang. 2008. Biologi Tanah. Pasca Sarjana UI. Jakarta

[15] Fiantis D. 2015. Morfologi Dan Klasifikasi Tanah.Penerbit: Minangkabau Pres.

[16] Christanto J. 2016. Analisis Sumber Daya Alam Dan Lingkungan. Penerbit: Erlangga. 